\title{
Ordinary and Special Breads: Eucharist and Temptation in Hansel and Gretel
}

\author{
Judith Lanzendorfer \\ University of Findlay, Ohio, USA
}

\begin{abstract}
This article focuses on how Hansel and Gretel, collected by Wilhelm and Jacob Grimm in Children's and Household Tales (1812) should be seen as more than a folktale for small children; it can, instead, be read as a highly theological work related to the Calvinist view of the Eucharist and directed more to young adults and adults. The Grimm brothers, who were strict Calvinists, viewed the tales as being useful in instilling moral lessons to children. As such, Hansel and Gretel can be seen as highlighting the tension between Calvinist and Catholic perspectives on the Eucharist. It is important when teaching the text to consider this culturally relative context. Doing so helps to highlight the original didactic purpose for Children's and Household Tales and how we can revisit and reclaim the moral initiative of the book in a modern context.
\end{abstract}

Keywords: Grimm, Calvinist, Eucharist, folktale

There have been many articles written about Hansel and Gretel, published by Wilhelm and Jacob Grimm in 1812 in Children's and Household Tales. Points of analysis have focused on gender and age (Henneberg, 2010), to the effect that the tale has on the psychological development of the audience members (Wittmann, 2011) to manifestations of the tale in modern media (Rudy \& Greenhill, 2014). Perhaps the most influential articles and books, though, are those by Jack Zipes, including the modern English translation of Children's and Household Tales (2014), to "Who's Afraid of the Brother's Grimm: Socialization and Politicization Through Fairy Tales" (1979-1980) to the "Use and Abuse of Folk and Fairy Tales with Children" (1977). In much of Zipes work, there is the emphasis of how the folk and fairy tales have a didactic purpose for the audience, specifically the middle-class. Zipes notes in the Preface to his translation of Children's and Household Tales (2014) of the Grimm brothers' "strict religious training in the Reform Calvinist Church" (xxiv), and that they "wanted to preserve, contain, and present to the German public what they felt were profound truths about the origins of civilization" through the folktales (xxx). Indeed, there was great emphasis on the didactic nature of the tales and "by the 1870s the Grimms' tales had been incorporated into the teaching curriculum in Prussia and other German principalities” (xxxiii).

It should be noted at this point that often there is a misunderstanding, especially among modern students, that Grimms' book is meant for the very young. Part of this misunderstanding may stem from the title of the work-Children's and Household Tales. Part of this misunderstanding may also come from the modern 
presentation of tales like Cinderella, Snow White, and Sleeping Beauty through the lens of Disney company films, which repackage the narrative to sanitize sexual and violent content so that it is consumable for young children. This was not, however, the original audience for the tales. Zipes notes in The Brothers Grimm: From Enchanted Forest to the Modern World (1988), that the Grimm brothers "had never planned to publish such a volume when they had begun collecting the tales, and they were not at all intended for children” (p. 10). Zipes (1988) continues that evidence for an older audience may easily be found in the fact that "the first two volumes had scholarly annotations", something clearly not intended for children (p. 28). Recognizing the original audience as older is important for this given study because the abstractness of argument that I propose is often too advanced for young children. It is the young adult or adult who would be able to grasp the nuances of symbolism in the tales and understand the religious commentary therein. It was this adult or young adult reader who was the intended audience until the 1819 revision in which Wilhelm made changes to the work to "conform to what he thought would be proper for children to learn” (p. 28). Even so, the brothers maintained the emphasis of the text as "an Erziehungsbuch, an educational manual” primarily for an older middle-class audience (p. 28).

Although a great debt is owed to Zipes for all of the books and articles that hecontributed to scholarship in his career, I find that Ronald Murphy's chapter on Hansel and Gretel in The Owl, The Raven and the Dove (2000) to be an important and compelling addition to Zipes's volume of work. Although Zipes does discuss how the religion of the brothers Grimm effected their worldview, Murphy complicates this by taking the position of how the Grimm brothers' texts can be read as tales that deal specifically with spiritual themes. Murphy notes regarding Hansel and Gretel that:

Wilhelm worked and meditated on this story until he made it a classical parable of the journey of the human soul from infancy to spiritual awareness of right and wrong, the journey of human salvation. He did this structurally by adding to the story an ending that requires the crossing of great water, and by inserting spiritual guidance in the form of the white dove which leads the children on. In vocabulary and tone he altered the function of the forest, the path, the unselfish love of the children for one another, so that there is hardly any person of religious faith who cannot but feel moved by this seemingly so simple tale. (2000, p. 53)

What is so interesting to me in the many fine points that Murphy makes in his analysis is that he leaves out one of the most obvious symbols of religious significance in the tale-bread. This article's focus is on the history of the role of bread in the ritual of the Eucharist in the Roman Catholic Church and its consequent reframing in Hansel and Gretel by the Calvinist Grimm brothers. In this way, bread, in its various forms, takes on a special resonance in the tale as both a symbol of redemption and a reminder of the perils of sin.

The importance of the Eucharist as a salient site of spirituality to the brothers is underscored by Jacob in his autobiography when he notes that, "Never was greater devotion ignited in me as on the day of my confirmation, after I had just received Holy Communion” (as qtd. in Zipes, 1988, p. 2). The importance of the Eucharist to the Grimms and the complications associated with it in their world view is a perspective that audiences who are unaware the cultural context of the timemay not recognize. It is important, however, to consider this culturally relative context when teaching Grimms' work as doing so helps the modern reader to understand the original didactic intent of the text. Indeed, as Jacob notes, "I used to regard the Lutherans, who lived right among us in our little country town, as strangers.... As far as the Catholics were concerned, they travelled through our town from Salmunster... and I formed some strange and fearful views of them” (qtd. in Zipes, 1988, p. 2). It is this world 
view, anyone who is not a Calvinist should be viewed with suspicion. Part of this suspicion derives from the rituals of the church, particularly how bread, in the Eucharist, is framed by different faiths. It is this through the depiction of bread in Hansel and Gretel that we find an exemplar of the Grimm brothers' Calvinist perspective on the importance of the tale.

\section{Quality of Bread Used in the Eucharist}

To begin to understand the significance of bread within the Christian culture of the Middle Ages to the time of the Grimm brothers, one needs to start with the presentation of the Eucharist in the oldest Christian sect, the Roman Catholic Church. There have been many articles that have been written about the importance of the host in Roman Catholic mass,with the doctrine of Transubstantiation being a large part of discussion. By the Fourth Council of the Lateran in 1215 it is noted that

His [Jesus's] body and blood are truly contained in the sacrament of the altar under the forms of bread and wine, the bread and wine having been changed in substance, by God's power, into his body and blood, so that in order to achieve this mystery of unity we receive from God what he received from us. (“Cannon 1: Confession of Faith", Fourth Lateran Council)

This statement in "Cannon 1: Confession of Faith” establishes that the idea of the literal transubstantiation of the host through mystical means into the body of Christ and was cemented in Roman Catholic doctrine by the High Middle Ages.

It is with this tradition of the host, itself, as being somehow mystical/magical because of it changes in substance to be "one and the same" as the body of Christ that we move to the early Reformation. Martin Luther takes up the concept of Transubstantiation in 1528 and asserts that it does not literally occur. Instead, Luther modifies the idea of Transubstantiation and presents instead the notion of "Sacramental Union". Luther notes in Confessions Concerning Christ's Supper (1528), later collected in the Book of Concord:

We believe, teach, and confess that the body and blood of Christ are received with the bread and wine, not only spiritually by faith, but also orally; yet not in a Capernaitic, but in a supernatural, heavenly mode, because of the sacramental union. ("The Holy Supper")

With the idea of Sacramental Union, the bread and wine in the Eucharist are not literally the body and blood of Christ, but are, in the language of the Wittenberg Concord of 1536 and later noted in the Book of Concord, "in and under the bread and wine", but not literally the body and blood as would occur in Transubstantiation ("The Holy Supper").

This idea of the mystical quality of bread used in a church service is further complicated when one considers the doctrine of John Calvin, the reformer whose theology was followed by Wilhelm and Jacob Grimm. Calvin noted concerning the Eucharist that we "really and indeed, yet not carnally and corporally, but spiritually, receive and feed upon Christ” (“Of the Lord's Supper”). From Calvin’s perspective, the presence of Christ in the bread was spiritual rather than a mystical/magical transformation that literally changed physical substance or was somehow "in and under" the physical substance. Thus, the bread that was eaten was just that, bread, and only representative of the body of Christ.

Also importantly, there was marked departure in Calvinist services from using a host, employed in the Roman Catholic and Lutheran traditions, to using "ordinary table bread" for the Eucharist. It was noted in the 
1578 synod of the Netherland Reformed Churches that the actual product used in Eucharist was a hot topic: as noted by Jesse Spohnholz in The Tactics of Toleration: A Refugee Community in the Age of Religious Wars, "Although the synod admitted that 'all churches should try to use ordinary bread' [for the Eucharist], if this was not possible 'no one should make a dispute about it'” (2010, p. 84). The fact that they needed to make special note about not disputing the actual product used in a Eucharist service underscores just how symbolic, for good or ill, the host and bread had become in the discussion of the Eucharist.

At this point, one might consider why there might be such concern over the product used in the Eucharistic rite. Why is there a preference for "ordinary bread"? The answer comes, again, from the 1578 Synod. In this synod, it was directed that ordinary bread was to be usedfor Eucharist "and not some special kind of unleavened bread or something else that smacks of superstition” (p. 83-84). In this discussion, there is a implication that one should not use a host for Eucharist. Certainly, there is a prescription by the Roman Catholic Church that:

The bread used in the celebration of the Most Holy Eucharistic Sacrifice must be unleavened, purely of wheat, and recently made so that there is no danger of decomposition. It follows therefore that bread made from another substance, even if it is grain, or if it is mixed with another substance different from wheat to such an extent that it would not commonly be considered wheat bread, does not constitute valid matter for confecting the Sacrifice and the Eucharistic Sacrament. ("The Proper Celebration of Mass")

This, in addition to the idea of Transubstantiation as a superstitions "magical” practice, likely fueled the Synod's desire for using "ordinary table bread” for the Eucharist. Indeed, by the time of Calvin, there was more emphasis placed on the symbolic nature of the Eucharist, rather than any sort of supernatural transformation, as one might find in Transubstantiation or even Sacramental Union. As explained by Keith Mathison,

According to Calvin the sacraments are signs. The signs and the things signified must be distinguished without being separated.... Calvin argues that when Christ uses the words, "This is my body", the name of the thing signified ("body") is applied to the sign (the bread). (“Calvin’s Doctine”).

So, for a Calvinist, there was no need for a host, for the idea of Transubstantiation or Sacramental Union; there could just be literal, ordinary bread because it was the idea and the symbol of Christ that was of importance. One might recall at this point the recollection of Jacob Grimm regarding the moment in his life when he felt the most spiritual fevor: "Never was greater devotion ignited in me as on the day of my confirmation, after I had just received Holy Communion” (as qtd. in Zipes, 1988, p. 2); this Holy Communion for the Calvinist Grimm would have been "ordinary table bread" and made an impression on him that lasted throughout his life.

\section{The Importance of Bread in Hansel and Gretel}

This information on the importance of bread in the Eucharist service brings one back to Hansel and Gretel and why bread is so important in the tale. Bread is one of the sites of revision from antecedents that one finds when reading the Grimm version versus earlier or contemporary versions of the tale. For instance, critics, such as Jean-Louis Hippolyte (1991) and Willem Blecort (2008), have pointed out that the version of Hansel and Gretel that the Grimm brothers include in their book is based in part upon Charles Perrault's 1697 Hop O'My Thumb (Le Petit Poucet) and, indeed, the connections between the Perrault and Grimm tales are very clear. There are, however, some differences between the tales and one of these centers upon bread. In the French version of the tale, it is noted that "crumbs" are used as a trail marker, but any other description or significance to this trail of crumbs 
is lacking. In the Grimm version, however, there is great expansion on this part of the text. As Zipes (1988) notes, the Grimm's made additions when editing their tales; they expanded sections of tales and "added numerous Christian expressions and references” in doing so (p. 28). As such in Hansel and Gretel, there is a much expanded description and emphasis placed on how Hansel has one small piece of bread that he breaks up into bread crumbs to mark the way: "on the way into the forest Hansel rumbled the bread in his pocket and stopped as often as he could to throw the crumbs on the ground... little by little Hansel managed to scatter all the bread crumbs on the path” (2014, p. 55). Here, Hansel sacrifices the only food that he has to try to save his sister and himself. Hansel has used his lunch for the breadcrumb trail and has nothing left to eat, so Gretel later also sacrifices by breaking her bread and sharing her little piece of bread with her brother: "Gretel hared her bread with Hansel, who had scattered his along the way" (2014, p. 55). Murphy makes note of this part of the text by remarking that, "The brother and sister deem it very natural, as does the reader unconsciously, for the one to sacrifice his bread to find a way back, and for the other to sacrifice half her bread for him” (2000, p. 54), but I think that this part of the text might be framed as more than simple sharing. If one considers the idea presented earlier that in the Calvinist tradition, from which Wilhelm and Jacob Grimm are reared, it is "ordinary bread" that is shared in the Eucharist, then what Hansel and Gretel do here may be seen as far more significant than just sharing their lunch. They take the ordinary bread that they have, break it, and eat it. Through the sacrifice that each makes and the action of breaking of the bread, Hansel and Gretel are reenacting the sacrifice that is remembered in the Eucharistic ritual. Just as Christ sacrifices his very life for sinners, the siblings may be seen as sacrificing their sustenance, that which keeps them alive, for each other.

Further, one might also consider where this breaking of bread occurs in the text. It appears just after the children are abandoned in the woods by their parents for the second time, but before three days of wandering in the woods. This inclusion, which is inserted by the Grimms and is not in source texts like Hop O’My Thumb, echoes the span of time from the Last Supper to the Resurrection. The Paschal Triuum begins with Maundy Thursday, with the introduction of the Eucharist rite of the Last Supper, and ends with Easter. This span of time, the holiest days of the church year, would have been part of the Reformed church that the Grimm's followed. If indeed, as Murphy (2000) asserts, that the tale is one about "the journey of human salvation", then the shared bread that is introduced on this day cannot be underestimated (p. 53). It can be viewed as putting in motion in the audience's mind the three days of sacrifice in the Paschal Triuum with the hope of redemption at the end of the journey.

It should be noted that at this point that one is already halfway through the folk text. When I use this tale in my classes and ask my students what they remember from their childhood about Hansel and Gretel, they invariably mention the gingerbread house, but are not aware of or remember the long section that comes before it. For the students, the tale is all about the gingerbread house, and indeed, at this point in the text the tale is all about the gingerbread house for two important reasons. First, if we are to accept the reading that the bread that Hansel and Gretel share in the woods is a form of the Eucharist, then the gingerbread house also may be seen as holding more significance than as just food. The gingerbread house in the folk tale is often glossed as representative of the destructive nature of temptation, especially in relation to the physical body (such as in Dan, 1991), but it is much more than this if one reflects upon the concerns of the members of the Dutch synod. The gingerbread house could very well represent one of those "special kinds of bread" (Spohnolz, 2010, p. 83) that "smacks of superstition” (p. 
84) which was so very concerning. Gingerbread is, indeed, not a typical bread that one would eat every day; it is a special bread and thus might be viewed as out of the ordinary, and perhaps a cause of concern.

Indeed, Hansel and Gretelshould be very concerned, for we learn that this house is the domain of a cannibalistic witch. The witch puts the two children into mortal physical peril, by caging Hansel and forcing Gretel into servitude. What should be more concerning, though, when one reads the tale from a religious perspective, is the peril of their souls from exposure to the "special bread" that has contaminated their bodies and forced them into sin. Murphy (2000) proposes that this section of the text be read as a test; he notes that "The test is old: the food [the gingerbread house] is forbidden. The children begin eating the house" and in doing so are reenacting the first sin of the Fall of Adam and Eve from the Garden of Eden (p. 59). Although I agree with the first part of Murphy's analysis about the gingerbread house being a test, I respectfully disagree with the last part of his statement. If one accepts that the bread that is shared is by Hansel and Gretel in the woods is the Eucharist, then they are already practicing Christians. The eating of the gingerbread house, therefore, is not the first fall, but a representation that even in a post-crucifixion/salvation world, mere mortals continue fall short of perfection.

If one were to follow the Paschal Triuum to its conclusion, then one should end with salvation through the Resurrection. In the text, though, there is no immediate salvation, but imprisonment. Why is there no immediate deliverance for these two siblings? This is the second significant point related to the gingerbread house. Hansel and Gretel's actions of eating the gingerbread house shows how they succumb to their base human needs even when confronted with an extraordinary gingerbread house in the woods that should be a site of caution and suspicion. Hansel and Gretel are defined by their base fallen state; as such, one might see their imprisonment as analogous to the Calvinist doctrine of "total depravity" which indicates how moral man is bound to sin. As noted in The Heidelberg Catechism’s Question 8 regarding total depravity:

Are we then so corrupt that we are wholly incapable of doing any good, and inclined to all wickedness?

Answer: Indeed we are; (a) except we are regenerated by the Spirit of God. (The Heidelberg Catechism)

In the Grimm's world, all men are born sinful because of the fall of Adam and Eve. The fall that Murphy notes as a "first sin”, therefore, from the Grimm brothers' worldview isn’t as much the act of Adam and Eve sinning, but the ramifications of their sin on the later world, including in the lives of Hansel and Gretel.

The time that Hansel and Gretel stay in the witch's house as her literal prisoners, which we might read as metaphorical prisoners of sin, is not defined; it may be considered a liminal period where time has no meaning and the normal social order is upturned (Turner, 1995). It is in this space that both Hansel and Gretel need to learn that in order to be freed from sin, they need to trust in God alone. Thus, how Hansel and Gretel are saved from imprisonment is significant. Gretel's laments:

It would have been better if the wild animals in the forest had eaten us. Then we would have died together and wouldn't have had to bear this sorrow, and I wouldn't have to boil the water that will be the death of my dear brother. Oh dear God, help us poor children get out of this predicament! (p. 48, emphasis added)

It is true that Gretel does trick the witch into the oven and is thus able to save her brother and herself, but she does so only after she says a prayer to God to "get out of this predicament”. She doesn't ask for God to "help me find a way", or "help me figure out an answer", but rather for God to "get [us] out". Here the emphasis is not on 
Gretel's individual actions, but on the actions and will of God. Bearing this in mind, Gretel, who may initially be framed as the "hero" at the end of the tale by some modern audiences, is not so much a hero as a vessel who God uses in a way that results in the siblings escaping the witch. Certainly Gretel does have a part to play, but her part is much less about her own personal will and power, and much more about how God's power is used through her in order to effect the siblings' escape. In this way, Gretel defines the idea of "irresistible grace”; salvation has nothing to do with her actions, but is attained through the intervention of God.

After the witch is killed, the ending of the tale comes very quickly. The children find jewels in the house and fill their pockets with riches and after a short journey find their way home to their father. It is important to make special mention of the inclusion of jewels at the end of the tale. Just as the bread in the tale can be seen as more than just bread, and Hansel's cage more than a cage, so the jewels that the siblings find after the defeat of the witch may be seen as more than just jewels. The "jewels and pearls" that they "filled their pockets with" can be viewed metaphorically. They echo and are reflective of Matthew 6:19-21 (2013):

Do not store up for yourselves treasures on earth, where moths and vermin destroy, and where thieves break in and steal. But store up for yourselves treasures in heaven, where moths and vermin do not destroy, and where thieves do not break in and steal. For where your treasure is, there your heart will be also.

This allusion to Matthew in Hansel and Gretel is another indication of how the Grimm brothers intended their texts to be read didactically, not just as a form of entertainment. The siblings in the text engage in a difficult journey where they, even though fortified by the Eucharist, are tested and found wanting. It is only when they turn to God that they are saved from sin and are rewarded with "jewels and pearls", their treasure in Heaven.

Like the references to jewels in the text having a significance greater than what one might initially suspect, the last phrase of the text—- "the mother had died"-is also weighted with importance. One may read the text from a psychoanalytic perspective, like Bruno Bettleheim does in Uses of Enchantment (1976) and which is expanded upon in Gerta-Elisabeth Wittmann's "When Love Shows Itself as Cruelty: The Role of the Fairy Tale Stepmother in the Development of the Underaged Reader" (2011). In such readings, the witch/mother are presented as two sides of the same being. Because of this, if the mother is evil and abandons her children in the woods early in the text, then when they encounter the witch, she must be evil in nature also. Likewise, if the witch is killed in the oven at toward the end of the text, then the mother must also be dead as well at the end. The last line, therefore, can be seen as acting almost an afterthought, a simple narrative device to "tie up the loose ends" of the tale and give it a neat, tidy ending.

This last phrase, however, takes on a resonance of much more importance if one reads it with the frame of the tale being a religious text in mind. Instead of the phrase being just an afterthought, it is a strong definitive ending to tale. From her part in the abandonment of the children to her tempting them with "special bread", the mother/witch seems to be put into the tale to be as test for the siblings. The siblings overcoming these tests is an indication not just of the defeat of a wicked woman, but the defeat of the corrupt belief system that the Calvinists wished to reform. It is not the host that saves the children or confession to a priest; it is "ordinary bread" which sustains them and a plea to God, himself, that saves them, both being sound Calvinist theology.

Hansel and Gretel may be seen are adolescents who have a dangerous and exciting journey in the woods; reading the tale on this level is entertaining and enjoyable. One must not forget, though, that the Grimm 
brothers collected, modified, and edited the tales in their volume not just to entertain, but also to teach. As Zipes (2014) notes, the Grimms "were convinced that their tales possessed essential truths about the origins of civilization" and that because of and to enhance this, they "imbued the tales with a heavy dose of Christian morality" (xxxv). The content of Hansel and Gretel addresses profound theological issues related to the Eucharist and the will of God. In this way, Hansel and Gretel is not just a tale about two small children who get lost in the woods and eat a gingerbread house, but a deeply profound tale centered on Calvinist theology about the Eucharist, sin and redemption.

\section{References}

Bettelheim, B. (1976). The uses of enchantment: The meaning and importance of fairy tales. New York: Knopf.

Blecourt, W. (2008). On the origin of Hansel und Gretel. Fabula, 49(1-2), 30-46.

Dan, D. (1991). Beyond the gingerbread house: Addiction, recovery, and esoteric thought. Quadrant: Journal of the C. G. Jung Foundation for Analytical Psychology, 24(2), 41-55.

Papal Encyclicals Online. (1215). Cannon 1: Confession of Faith. Fourth Lateran Council. http://www.papalencyclicals.net/councils/ecum12-2.htm

Grimm, J., \& Grimm, W. (2014). Hansel and Gretel. In J. Zipes (Ed.), The complete first edition: The folk \& fairy tales of the brothers Grimm (pp. 43-49). Princeton, NJ: Princeton UP.

Henneberg, S. (2010). Moms do badly but Grandmas do worse: The nexus of sexism and ageism in children's classics. Journal of Aging Studies, 24(2), 125-134.

Hippolyte, J. (1991). Étude Comparee du "Petit Poucet” de "Hansel et Gretel” des Freres Grimm (Compared Study of the "Tom Thumb” of the "Hansel and Gretel” of Brother’s Grimm). Merveilles \& Contes, 5(2), 390-402.

Mathison, K. (2006). Calvin's doctrine of the lord's supper. Ligonier ministries. http://www.ligonier.org/learn/articles/calvins-doctrine-lords-supper/

Murphy, G. R. (2000). The owl, the raven, and the dove: The religious meaning of the Grimms' magic fairy tales. New York: Oxford UP.

New International Version Bible. (2013). New York: Zondervan.

Of the Lord's supper. Center for Reformed Theology and Apologetics. http://www.reformed.org/documents/wcf_with_proofs/index.html?body=/documents/wcf_with_proofs/ch_XXIX.html

Rudy, J., \& Greenhill, P. (2014). Channeling wonder: Fairy tales on television. Detroit, MI: Wayne State University Press.

Spohnholz, J. (2010). The tactics of toleration: A refugee community in the age of religious wars. Newark, DE: University of Delaware Press.

The Heidelberg catechism. Center for Reformed Theology and Apologetics. https://www.crcna.org/welcome/beliefs/confessions/heidelberg-catechism

The Holy supper. The book of concord: Confessions of the Lutheran church. http://bookofconcord.org/defense_8_holysupper.php

The proper celebration of mass: The matter of the most Holy Eucharist. Redemptionis sacramentum. http://www.vatican.va/roman_curia/congregations/ccdds/documents/rc_con_ccdds_doc_20040423_redemptionis-sacramentu m_en.html

Turner, V. (1995). The ritual process: Structure and anti-structure. New York: Routlage.

Wittmann, G. (2011). When love shows itself as cruelty: The role of the fairy tale stepmother in the development of the underaged reader. Mousaion, 29(3), 1-11.

Zipes, J. (1977). On the use and abuse of folk and fairy tales with children. Telos, 32, 215-244.

Zipes, J. (1988). The brothers Grimm: From enchanted forests to the modern world. NewYork: Routledge.

Zipes, J. (1979-1980). Who's afraid of the brothers Grimm: The socialization and politicization through fairy tales. The Lion and the Unicorn, 3(2), 4-41. 